\title{
New approach for congenital CMV infection diagnosis in neonates: sensibility and specificity of CMV detection in dried blood spots Marianne Leruez-Ville*1,6, Christelle Vauloup-Fellous ${ }^{2}$, Sophie Couderc ${ }^{4}$, Sophie Parat ${ }^{3}$, Salima Oucherif ${ }^{3}$ and Jean-François Magny ${ }^{5}$
}

Address: ${ }^{1}$ Hôpital Necker-Enfants-malades, AP-HP, National Reference Center for Cytomegalovirus, Paris, France, ${ }^{2}$ Hôpital Antoine Bèclère, APHP, Virologie, Clamart, France, ${ }^{3}$ Hôpital Necker-Enfants malades, Maternité, Paris, France, ${ }^{4}$ Hôpital de Poissy, Maternité, Poissy, France, 5 Institut de Puériculture, Néonatalogie, Paris, France and ' $U$ nniversité Paris-Descartes EA 36-20, Paris, France

* Corresponding author

from Fifth Dominique Dormont International Conference. Mother-to-child transmitted viral diseases: from transmission to children care Paris, France. 26-28 March 2009

Published: 22 July 2009

Retrovirology 2009, 6(Suppl I):OI2 doi:I0.II86/I742-4690-6-SI-OI2

This abstract is available from: http://www.retrovirology.com/content/6/SI/OI2

(c) 2009 Leruez-Ville et al; licensee BioMed Central Ltd.

\section{Background}

Detection of CMV DNA in DBS (Guthrie cards) has been proposed for neonatal diagnosis of CMV congenital infection.

\section{Objectives}

To evaluate the in vitro sensitivity of 2 methods of CMV DNA detection in DBS. To evaluate the specificity and the sensitivity of these 2 methods for congenital CMV diagnosis in comparison to the gold standard method (CMV detection in urine).

\section{Methods}

To study in vitro sensitivity, "test cards" were prepared with dilutions of pre-quantified whole blood samples. To study in vivo specificity and sensitivity, 215 neonates who had CMV congenital infection diagnosis done by PCR or culture in a urine sample collected in the first week of life were included prospectively. Fourty-five of these neonates had positive CMV detection in their urine (by PCR (Necker, Poissy, Béclère) or by rapid culture (IPP). CMV DNA was detected in the Guthrie cards by 2 methods. Method 1 consisted of DNA extraction in a whole DBS with $\mathrm{NaOH} 0.32 \%$ lysis followed by QIAamp DNA Blood Mini Kit and amplification by an in house real time PCR in duplicate. Method 2 was a phenol/chloroform extraction of a whole DBS followed by amplification with the CMV PCR kit (Abbott, France).

\section{Results}

The 95\% sensitivity of the 2 methods was 4000 and 2000 copies/ml respectively. In neonates, sensitivity and specificity of method 1 were 100\% (45/45) and 96.9\% (160/ $165)$ when at least one duplicate was positive and $88.8 \%$ (40/45) and 100\% (165/165) when the two duplicates were positive. Sensitivity and specificity of method 2 were $95.1 \%$ (39/41) and 97.5\% (158/162) respectively. Results were discordant (negative detection in urine and positive PCR in DBS) in 8 cards from 8 different neonates ( 4 with method 1 and 4 with method 2), these false positive were not repeatable when retested. Mean viral load of the 8 false positive were 376 [280-500] and 31 [9-53] copies/ $\mathrm{ml}$ with method 1 and method 2 respectively. In one case, the CMV PCR in DBS was repeatedly positive with the 2 methods, whereas it was negative in the urine at birth by rapid culture. This case was considered as a false negative of the rapid culture and was therefore excluded from the analysis.

\section{Conclusion}

Sensitivity of CMV DNA detection in DBS was very high when PCR was done in duplicate. However, when only one duplicate was positive it could be a false positive result. Low positive results needed to be confirmed by a second testing. In these best conditions, we think that these 2 methods are sensitive and specific enough for neonatal diagnosis of CMV congenital infection and for retro- 
spective diagnosis in children presenting with hearing loss.

Publish with Bio Med Central and every scientist can read your work free of charge

"BioMed Central will be the most significant development for disseminating the results of biomedical research in our lifetime." Sir Paul Nurse, Cancer Research UK

Your research papers will be:

- available free of charge to the entire biomedical community

- peer reviewed and published immediately upon acceptance

- cited in PubMed and archived on PubMed Central

- yours - you keep the copyright

Submit your manuscript here:

http://www.biomedcentral.com/info/publishing_adv.asp 